\title{
PENGARUH KUALITAS PRODUK, HARGA, PROMOSI DAN TEMPAT PENDISTRIBUSIAN TERHADAP KEPUTUSAN PEMBELIAN SEPEDA MOTOR YAMAHA PADA CV. TJAHAJA BARU BUKITTINGGI
}

\author{
THE EFFECT OF PRODUCT QUALITY, PRICE, PROMOTION AND \\ DISTRIBUTION PLACE ON PURCHASHING DECISION OF YAMAHA \\ MOTORCYCLE IN CV. TJAHAJA BARU BUKITTINGGI
}

\author{
Hariman Syaleh \\ Sekolah Tinggi Ilmu Ekonomi Haji Agus Salim Bukittinggi \\ harimansyaleh@yahoo.co.id
}

\begin{abstract}
Yamaha as a growing automotive company today realizes the importance of strategy in winning market competition. This research aims to determine the effect of product quality, price, promotion and istribution place on purchasing decision of yamaha motorcycle in CV. Tjahaja Baru Bukittinggi. Sample of this research are 96 customers who buy Yamaha motorcycle in CV. Tjahaja Baru Bukittinggi which is chosen by accidental sampling technique. Variables used in this research are of Product (X1), Price (X2), Promotion (X3) and Distribution (X4) as independent variable and purchase decision as dependent variable. Data analysis technique used is multiple linear regression. The result of this study indicate that the product, promotion and distribution have a positive and significant effect on purchasing decision of Yamaha motor in CV. Tjahaja Baru Bukittinggi, while price has a positive but not significant effect on purchasing decision of Yamaha motor in CV. New Tjahaja Bukittinggi.
\end{abstract}

Keywords: Products, Price, Promotion, Distribution, Buying decision

\begin{abstract}
ABSTRAK
Yamaha sebagai perusahaan otomotif yang sedang berkembang saat ini menyadari pentingnya strategi dalam memenangkan persaingan pasar. Penelitian ini bertujuan untuk mengetahui pengaruh Kualitas Produk, Harga, Promosi dan tempat pendistribusian terhadap Keputusan Pembelian Sepeda Motor Yamaha pada CV. Tjahaja Baru Bukittinggi. Sampel dalam penelitian ini adalah 96 pelanggan yang membeli sepeda motor Yamaha di CV. Tjahaja Baru Bukittinggi yang dipilih menggunakan teknik accidental sampling. Variabel yang digunakan dalam penelitian ini terdiri dari Produk $\left(X_{1)}\right.$, Harga $\left(X_{2}\right)$, Promosi $\left(X_{3}\right)$, Distribusi $\left(X_{4}\right)$ sebagai variable bebas dan keputusan pembelian (Y) sebagai variable terikat. Teknik analisis data dalam penelitian ini menggunakan metode regresi linear berganda. Hasil penelitian ini menunjukkan bahwa produk, promosi dan distribusi berpengaruh positif dan signifikan terhadap terhadap keputusan pembelian motor Yamaha di CV. Tjahaja Baru Bukittinggi, sedangkan harga berpengaruh positif dan tidak signifikan terhadap keputusan pembelian motor Yamaha di CV. Tjahaja Baru Bukittinggi.
\end{abstract}

Kata Kunci : Produk, Harga, Promosi, Distribusi, Keputusan Pembelian 


\section{PENDAHULUAN}

Tingkat persaingan dunia usaha di Indonesia sangat ketat, karena setiap perusahaan berusaha untuk dapat meningkatkan persaingan pasar dan meraih konsumen baru. Perusahaan harus dapat menentukan strategi pemasaran yang tepat agar usahanya dapat bertahan dan memenangi persaingan, sehingga tujuan dari perusahaan tersebut dapat tercapai. Pada dasarnya semakin banyak pesaing maka semakin banyak pula pilihan bagi pelanggan untuk dapat memilih produk yang sesuai dengan harapannya. Sehingga konsekuensi dari perubahan tersebut adalah pelanggan menjadi lebih cermat dan pintar menghadapi setiap produk yang diluncurkan.

Dalam proses penyampaian produk kepada pelanggan dan untuk mencapai tujuan perusahaan yang berupa penjualan produk yang optimal, maka kegiatan pemasaran dijadikan tolak ukur oleh setiap perusahaan. Sebelum meluncurkan produknya perusahaan harus mampu melihat atau mengetahui apa yang dibutuhkan oleh konsumen. Jika seorang pemasar mampu mengidentifikasi kebutuhan konsumen dengan baik, mengembangkan produk berkualitas, menetapkan harga, serta mempromosikan produk secara efektif, maka produkproduknya akan laris dipasaran .

Perusahaan harus mampu mengenal apa yang menjadi kebutuhan dan harapan konsumen saat ini maupun yang akan datang. Konsumen sebagai individu dalam mendapatkan atau membeli barang telah melalui proses-proses atau tahapan-tahapan terlebih dahulu seperti mendapat informasi baik melalui iklan atau referensi dari orang lain kemudian membandingkan produk satu dengan produk lain sampai akhirnya pada keputusan membeli produk itu.

Demikian juga terjadi pada perusahaan otomotif di Indonesia, khususnya sepeda motor. Dengan banyaknya perusahaan otomotif yang ada di Indonesia, maka konsumen akan lebih selektif dalam menentukan merek sepeda motor yang digunakan sebagai alat transportasi. Munculnya produsen sepeda motor dari Cina semakin memperketat persaingan industri sepeda motor di Indonesia.

Namun hingga saat ini sepeda motor Jepang tetap menjadi pilihan utama bagi masyarakat Indonesia karena berbagai macam keunggulan yang dimilikinya. Keputusan konsumen dalam menentukan atau memilih merek sepeda motor tertentu bukanlah hal yang begitu saja terjadi. Banyak pertimbangan yang dilakukan konsumen sebelum memutuskan untuk membeli suatu produk misalnya, kualitas produk, harga, dan iklan.

Yamaha sebagai perusahaan otomotif yang sedang berkembang saat ini telah menyadari persaingan ini. Yamaha senantiasa memberikan keyakinan dan harapan kepada para pelanggannya untuk terus memberikan kepuasan kepada mereka. Di Indonesia banyak terdapat distributor produk Yamaha, salah satunya yaitu CV. Tjahaja Baru yang merupakan salah satu distributor sepeda 
motor Yamaha yang ada di Jalan Soekarno-Hatta No. 8 Kota Bukittinggi. CV.Tjahaja Baru menjual berbagai macam item sepeda motor diantaranya Yamaha Vega, Yamaha Jupiter, Yamaha Nouvo, Yamaha Mio, Yamaha Jupiter MX, Yamaha F1ZR,Yamaha Scorpio, dan Yamaha F-Xion .

Dalam strategi pemasaran produk CV. Tjahaja Baru menggunakan bauran pemasaran yang terdiri atas empat (4) variabel yaitu strategi produk (product), strategi harga (price), strategi tempat (place) dan strategi promosi (promotion). Dalam pelaksanaan pengembangan penjualan dapat disesuaikan dengan selera konsumen, dengan harapan agar konsumen merasa puas atas produk dan jasa yang telah diberikan atau diperjual belikan.

Berikut data penjualan $\mathrm{CV}$ Tjahaja Baru 5 tahun terakhir :

Tabel 1 Data Penjualan 5 Tahun Terakhir (dalam Rp)

\begin{tabular}{crrrrr}
\hline Merk & \multicolumn{1}{c}{$\mathbf{2 0 1 2}$} & $\mathbf{2 0 1 3}$ & $\mathbf{2 0 1 4}$ & \multicolumn{1}{c}{$\mathbf{2 0 1 5}$} & \multicolumn{1}{c}{$\mathbf{2 0 1 6}$} \\
\hline Honda & 275.993 & 602.488 & 896.560 & 74.183 & 897.030 \\
\hline Yamaha & 495.858 & 897.030 & 174.536 & 1.261 .070 & 1.174 .536 \\
\hline Suzuki & 82.643 & 116.598 & 196.101 & 151560 & 116.598 \\
\hline Other & 6.370 & - & - & 74.183 & 896.560 \\
\hline Total & $\mathbf{8 6 0 . 8 6 4}$ & $\mathbf{1 . 6 1 6 . 1 1 6}$ & $\mathbf{1 . 2 6 9 . 1 9 7}$ & $\mathbf{1 . 5 6 0 . 9 9 6}$ & $\mathbf{3 . 0 8 4 . 7 2 4}$ \\
\hline \multicolumn{5}{c}{ Sumber : CV Tjahaja Baru 2017}
\end{tabular}

CV. Tjahaja Baru berusaha untuk menjual produk yang berkualitas dan mempunyai nilai lebih dibandingkan dengan produk pesaing, misalnya Yamaha Mio. Yamaha Mio adalah sepeda motor yang berjenis skuter matic. Dalam peluncuran perdananya sudah langsung menarik konsumen dan menjadi market leader untuk produk sepeda motor matic. Di samping itu, kita telah mengetahui bahwa Yamaha menjadi perusahaan sepeda motor terbaik dalam pergelaran seri MotoGP tahun 2008 dan 2009. Hal ini telah membuktikan bahwa sepeda motor Yamaha mempunyai kualitas mesin terbaik dibandingkan dengan yang lain.

Di samping kualitas produk, tinjauan terhadap harga juga semakin penting, karena setiap harga yang ditetapkan perusahaan akan mengakibatkan tingkat permintaan terhadap produk berbeda. Dalam sebagian besar kasus, biasanya permintaan dan harga berbanding terbalik, yakni semakin tinggi harga, semakin rendah permintaan terhadap produk. Demikian sebaliknya, semakin rendah harga, semakin tinggi permintaan terhadap produk . Oleh karena itu, penetapan harga yang tepat perlu mendapat perhatian yang besar dari perusahaan.

CV. Tjahaja Baru dalam menjual produknya juga memperhatikan harga dengan kualitas produknya. Untuk lebih menarik konsumen, CV. Tjahaja Baru memberikan potongan langsung dan hadiah langsung kepada konsumen yang membeli sepeda motor Yamaha tipe tertentu secara tunai, atau lebih dikenal dengan cash back. CV. Tjahaja Baru juga menerima pembayaran secara berjangka (cicilan) yang jangka waktunya antara 12 bulan 48 bulan. Konsumen berhak memilih jangka waktu pembayaran sesuai dengan uang muka yang telah disetorkan.

Selain menawarkan produk yang berkualitas dan penetapan 
harga yang tepat, kemampuan perusahaan dalam mengkomunikasikan produk kepada konsumen melalui kegiatan promosi juga merupakan suatu hal penting. Promosi merupakan kegiatan yang dilakukan perusahaan untuk menonjolkan keistimewaan- keistimewaan produk dan membujuk konsumen untuk membeli. Perlu diketahui bahwa betapa bagusnya suatu produk bila konsumen belum pernah mendengarnya dan tidak yakin terhadap produk tersebut, maka calon konsumen tidak akan melakukan pembelian.

Dari latar belakang masalah dan penjelasan yang telah diuraikan sebelumnya, dapat diketahui bahwa rumusan masalah dalam penelitian ini adalah: Bagaimana pengaruh kualitas produk, harga, prmosi dan tempat pendistribusian terhadap keputusan pembelian sepeda motor Yamaha pada CV. Tjahaja Baru Bukittinggi." mengembangkan dan menguji kebenaran suatu pengetahuan. Dengan rumusan masalah yang ada maka dapat ditetapkan tujuan penelitian ini, yaitu: Untuk mengetahui pengaruh kualitas produk, harga, promosi, dan tempat pendistribusian terhadap pembelian sepeda motor Yamaha pada CV. Tjahaja Baru Bukittinggi.

Menurut Nitisemito (2010) pemasaran adalah semua kegiatan yang bertujuan untuk memperlancar arus barang dan jasa dari produsen ke konsumen secara paling efisien dengan maksud untuk menciptakan pemasaran yang efektif. Menurut Kotler dan Amstrong (2012) pemasaran adalah proses sosial dan manajerial dimana pribadi atau organisasi memperoleh apa yang mereka butuhkan dan inginkan melalui penciptaan dan pertukaran nilai dengan yang lain. Stanton (2012) mengemukakan pengertian pemasaran adalah suatu sistem dari kegiatan bisnis yang dirancang untuk merencanakan, menentukan harga, mempromosikan, dan mendistribusikan produk yang dapat memuaskan keinginan dalam mencapai tujuan perusahaan. Dari beberapa definisi diatas dapat disimpulkan bahwa pemasaran adalah suatu sistem dan kegiatan yang bertujuan untuk memuaskan keinginan konsumen dan mencapai tujuan dari perusahaan.

Bauran pemasaran terdiri dari empat variabel yaitu produk, harga, distribusi, dan promosi merupakan himpunan variabel yang dapat dikendalikan perusahaan untuk mempengaruhi tanggapan konsumen dalam pasar sasarannya (Kotler dan Amstrong, 2012). Dalam menjalankan bauran pemasaran tentu perusahaan akan dikaitkan dengan biaya pada masing-masing variabel bauran pemasaran.

Kualitas produk adalah kemampuan produk untuk memuaskan kebutuhan atau keinginan konsumen (Kotler dan Amstrong, 2012). Definisi lain kualitas produk adalah karakteristik produk atau jasa yang bergantung pada kemampuannya untuk memuaskan kebutuhan konsumen yang dinyatakan atau diimplikasikan (Kotler dan Armstrong,2012). Menurut Kotler dan Keller (2016), kualitas produk adalah totalitas fitur dan karakteristik produk atau jasa 
yang bergantung pada kemampuannya untuk memuaskan kebutuhan yang dinyatakan atau tersirat. Tantangan paling besar dihadapi oleh setiap perusahaan adalah masalah pengembangan produk. Pengembangan produk dapat dilakukan oleh personalia dalam perusahaan dengan cara mengembangkan produk yang sudah ada. Di samping itu juga dapat menyewa para peneliti guna menciptakan produk baru dengan model-model yang sesuai. Perusahaan yang tidak mengadakan atau tidak mampu menciptakan produk baru akan menghadapi resiko seperti penurunan volume penjualan, karena munculnya pesaing yang lebih kreatif, adanya perubahan selera konsumen, munculnya teknologi baru dalam proses produksi (Kotler dan Keller, 2016).

1. Produk : Produk adalah sesuatu yang bisa ditawarkan oleh produsen sebagai usaha untuk mencapai tujuan organisasi melalui pemenuhan kebutuhan dan keinginan konsumen (Tjiptono, 2015).

2. Harga : Harga merupakan nilai yang ditukarkan konsumen untuk memperoleh manfaat dari memiliki atau menggunakan produk. Dalam penetapan harga perusahaan ada beberapa strategi yang dapat diambil. Oleh karena itu harga selalu menjadi bagian penting dalam keputusan pemasaran.

3. Distribusi : Distribusi merupakan kegiatan perusahaan untuk memperlancar dan mempermudah penyampaian barang dan jasa dari produsen ke konsumen. Ada dua jenis saluran distribusi yang biasa dipilih perusahaan yaitu distribusi langsung dan distribusi tidak langsung.

4. Promosi : Promosi adalah sarana perusahaan untuk mengenalkan dan memberi informasi produknya kepada calon konsumen. Ada beberapa teknik promosi yang digunakan seperti penjualan perseorangan, pameran dan periklanan.

Menurut Kotler (2016), dalam tahap evaluasi, para konsumen membentuk preferensi atas merek-merek yang ada di dalam kumpulan pilihan. Konsumen tersebut juga dapat membentuk niat untuk membeli merek yang paling disukai. Dalam melaksanakan niat pembelian, konsumen tersebut dapat membuat lima sub-keputusan pembelian: keputusan merek, keputusan pemasok, keputusan kuantitas, keputusan waktu, dan keputusan metode pembayaran. Berikut ini adalah model sederhana pembuatan keputusan konsumen yang dikemukakan oleh Prasetijo dan Ihalauw (2005), yaitu :

1. Input

Komponen input merupakan pengaruh-pengaruh eksternal sebagai sumber informasi tentang produk tertentu dan mempengaruhi nilai yang berhubungan dengan produk, sikap dan perilaku konsumen. Input yang utama adalah kegiatan-kegiatan bauran pemasaran dan pengaruhpengaruh sosial budaya.

a. Input Pemasaran : Aktivitasaktivitas pemasaran merupakan usaha langsung untuk menjangkau, menginformasikan dan membujuk konsumen agar membeli dan menggunakan 
produk tertentu. Usaha-usaha tersebut meliputi bauran pemasaran barang (4P) dan jasa (7P).

b. Pengaruh Sosial Budaya : Lingkungan sosial budaya yang dimaksud antara lain, keluarga, sumber informal, sumber non informal, kelas sosial, budaya dan sub budaya.

2. Proses

Komponen
memperhatikan $\begin{array}{r}\text { proses } \\ \text { bagaimana }\end{array}$
konsep psikologis terkait.

3. Output

Komponen output menunjuk kepada dua macam kegiatan pasca keputusan pembelian yang saling berhubungan erat, yaitu perilaku beli (pembelian coba dan pembelian ulang) dan evaluasi pasca beli.

Harga adalah salah satu menghasilkan pendapatan, unsur lainnya menghasilkan biaya (Kotler, 2016). Konsumen dalam mengambil keputusan untuk membeli suatu produk yang ditawarkan banyak dipengaruhi oleh persepsinya terhadap price, product, promotion, place (marketing mix) yang telah diterapkan oleh perusahaan selama ini (Kotler,2016). Hubungan antara harga dengan keputusan pembelian yaitu harga mempengaruhi keputusan konsumen dalam melakukan pembelian, semakin tinggi harga maka keputusan pembelian semakin rendah, sebaliknya jika harga rendah keputusan pembelian berubah semakin tinggi (Kotler dan Amstrong, 2012).
Kerangka pikir penelitian menggambarkan hubungan antara variabel independen, dalam hal ini adalah kualitas produk (X1), harga (X2), dan promosi/iklan(X3) dan tempat (X4) pendistribusian terhadap variabel dependent yaitu keputusan pembelian(Y).Adapun kerangka pemikiran yang digunakan adalah sebagai berikut :

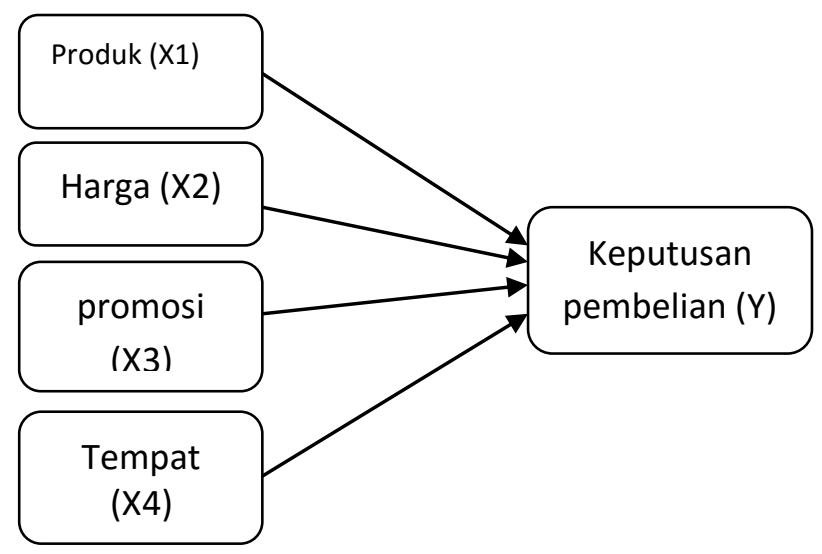

Gambar 1

Kerangka pemikiran

Sumber : Data yang diolah sendiri

Berdasarkan latar belakang, masalah dan permasalahan serta kerangka pemikiran, maka hipotesis dalam penelitian ini, diduga:

H1.Terdapat pengaruh Produk (X1) terhadap keputusan pembelian motor Yamaha pada CV.Tjahaja Baru di Bukittinggi.

H2. Terdapat pengaruh Harga (X2) terhadap keputusan pembelian motor Yamaha pada CV.Tjahaja Baru di Bukittinggi.

H3. Terdapat pengaruh Iklan / Promosi (X3) terhadap keputusan pembelian motor Yamaha pada CV.Tjahaja Baru di Bukittinggi.

H4. Terdapat pengaruh Tempat/Pendistribusian (X4) terhadap keputusan pembelian 
motor Yamaha pada CV.Tjahaja Baru di Bukittinggi. H5.Terdapat pengaruh Bauran Pemasaran (Produk, Harga, Promosi dan Tempat/Pendistribusian) terhadap keputusan pembelian sepeda motor Yamaha pada CV.Tjahaja Baru di Bukittinggi.

\section{METODE PENELITIAN}

Untuk menganalisa data yang diperoleh dari responden digunakan analisis kuantitatif, yaitu analisa berdasarkan metode statistik dan mengklasifikasikan data ke dalam kategori tertentu dengan menggunakan tabel untuk mernpermudah analisa.

\section{Populasi Dan Sampel}

Menurut Sugiyono (2012), populasi adalah sebagai wilayah generalisasi yang terdiri atas obyek atau subyek yang mempunyai kualitas dan karakteristik tertentu yang ditetapkan oleh peneliti untuk dipelajari dan kemudian ditarik kesimpulannya. Sedangkan sampel menurut Sugiyono (2012) adalah sebagian dari populasi itu yang memiliki karakteristik sama dengan populasi. Dalam penelitian ini pengambilan sampel dapat menggunakan rumus yang dikutip dari Sugiyono (2012), dikarenakan jumlah populasi yang tidak diketahui menggunakan rumus sebagai berikut

$$
n=\frac{1}{4}\left[\frac{z \alpha / 2}{E}\right]^{2}
$$

Keterangan :

$\mathrm{n}=$ Jumlah sampel dari jumlah populasi yang ingin diperoleh $\mathrm{Z}=$ Angka yang menunjukkan penyimpangan nilai varians dari mean
$\mathrm{E}=$ Kesalahan maksimal yang mungkin dialami

$a=$ Tingkat kesalahan data yang dapat ditoleransi oleh peneliti

Bila tingkat kepercayaan $95 \%$ $(a=5 \%)$, artinya peneliti meyakinin kesalahan duga sampel hanya sebesar 5\% serta batas error sebesar $10 \%$ yang berarti peneliti hanya mentolerir kesalahan responden dalam proses pencarian data tidak boleh melebihi jumlah $10 \%$ dari keseluruhan responden maka besarnya sampel adalah:

$$
\begin{aligned}
n & =\frac{1}{4}\left[\frac{z 0,05 / 2}{0,1}\right]^{2} \\
& =\frac{1}{4}[384,16]=96
\end{aligned}
$$

Berdasarkan perhitungan diatas, maka sampel yang dibutuhkan dalam penelitian ini adalah sejumlah 96 responden yang membeli motor Yamaha di CV. Tjahaja Baru.

Metode pengumpulan data pada penelitian ini adalah menggunakan teknik wawancara digunakan sebagai teknik pengumpulan data, apabila peneliti ingin melakukan studi pendahuluan untuk menemukan permasalahan yang harus diteliti, dan juga apabila peneliti ingin mengetahui hal-hal dari responden yang lebih mendalam dan juga jumlah respondennya sedikit/kecil (Sugiyono, 2012). uesioner merupakan teknik pengumpulan data yang dilakukan dengan cara memberikan seperangkat pertanyaan atau pernyataan tertulis kepada responden untuk dijawab (Sugiyono, 2012).

Adapun definisi operasional dalam penelitian ini adalah produk 
(kualitas produk, manfaat, jenis produk), Harga (harga produk, fasilitas diskon, pembayaran kredit atau tunai), tempat (lokasi distribusi, persediaan, transportasi), promosi (iklan, kontak langsung, demonstrasi, pemberian hadiah),

\section{Analisis Regresi Berganda}

Analisis Regresi Linear

Berganda adalah alat analisis ini digunakan untuk mengetahui apakah ada pengaruh positif dari variabel independen (X1, X2, X3 dan X4) terhadap variabel dependen (Y) dengan model regresi sebagai berikut :

$\mathrm{Y}=\mathrm{a}+\mathrm{b} 1 \mathrm{x} 1+\mathrm{b} 2 \times 2+\mathrm{b} 3 \times 3+\mathrm{b} 4 \times 4$

Keterangan:

$\mathrm{a}=$ Konstanta

$\mathrm{b}=$ Koefisien regresi

$\mathrm{Y}=$ Keputusan pembelian

$\mathrm{X} 1=$ Kualitas Produk

$\mathrm{X} 2=$ Harga

$\mathrm{X} 3=$ Promosi

$\mathrm{X} 4=$ Tempat Pendistribusian

Koefisien Determinasi $\left(\mathbf{R}^{2}\right)$

Untuk mengetahui berapa besar pengaruh Bauran pemasaran (X) terhadap keputusan pembelian motor Yamaha di CV. Tjahaja Baru kota Bukittinggi (Y) dan hubungan dua variabel dapat dihitung dengan menentukan koefisien determinan $\left(\mathrm{R}^{2}\right)$ yang besarnya antara 0 sampai 1 atau $0 \leq R^{2} \leq 1$. Jika $R^{2}$ mendekati 1, maka variabel independen berpengaruh terhadap variabel dependen dengan sempurna atau terdapat suatu kecocokan yang sempurna (variabel independen yang dipakai dapat menerangkan dengan baik variabel dependen). Namun jika koefisien determinasi adalah nol (0) berarti variabel independen tidak berpengaruh terhadap variablel dependen. Koefisien determinasi dalam penelitian ini adalah mengukur kontribusi variabel harga (X1), Kualitas Produk (X2), Harga (X3), Iklan dan (X4), Tempat Pendistribusian (X5) terhadap Keputusan Pembelian (Y).

\section{Uji Analisis data}

Untuk membuktikan

hipotesis dalam penelitian ini apakah variabel bebas berpengaruh terhadap variabel terikat, maka digunakan beberapa pengujian yaitu uji-t dan uji-F

Uji-t

Uji ini untuk mengetahui pengaruh masing-masing variabel independent terhadap variabel dependen secara parsial, apakah mempunyai pengaruh yang signifikan atau tidak.

Langkah-langkah pengujian:

1) Menentukan formulasi hipotesis alternatif nihil dan hipotesis alternatif

Ho : tidak ada pengaruh yang signifikan secara parsial variabel independen tehadap variabel dependen)

$\mathrm{Ha}$ : ada pengaruh yang signifikan secara parsial variabel independen tehadap variabel dependen)

2) Batasan t hitung Ho : tidak dapat ditolak bila sig. $>\alpha=0,05$ Ho : ditolak bila sig. $\leq \alpha=0,05$, Uji -F

Untuk menguji apakah masing-masing variabel independen berpengaruh terhadap variabel dependen secara bersama-sama.

Langkah-langkah pengujian:

1) Menentukan formulasi hipotesis alternatif nihil dan hipotesis alternatif

2) Batasan F hitung 
Ho : tidak dapat ditolak bila sig.

$>\alpha=0,05$ dan Ho : ditolak bila sig. $\leq \alpha=0,05$

\section{HASIL DAN PEMBAHASAN Pengujian Instrumen Penelitian Uji Validitas}

Uji validitas data yang didapatkan dari penyebaran angket terhadap 120 responden dengan level signifikansi 0.05 (5\%) dengan bantuan computer SPSS 17.00 berikut ini: Berdasarkan analisa yang dilakukan untuk jumlah sampel sebanyak $30 \quad(n=30)$ responden item.

Tingkat validitas yang merupakan korelasi antara skor item dengan total item (nilai $\mathrm{r}$ hitung) dibandingkan dengan nilai $r$ tabel. Jika $\mathrm{r}$ hitung > dari $\mathrm{r}$ tabel maka item tersebut valid (Arikunto : 2010). Nilai $r$ tabel untuk $\alpha 0.05$ dan $\mathrm{n}=$ adalah 0,361. Hasil uji validitasnya dapat dilihat dari masing-masing independen dan variabel pada Tabel 1 :

\section{Tabel 2 Hasil Uji Validitas} variabel kualitas produk

\begin{tabular}{cccc}
\hline $\begin{array}{c}\text { No Item } \\
\text { Pernyataan }\end{array}$ & $\begin{array}{c}\text { Nilai } \mathbf{r} \\
\text { Hitung }\end{array}$ & $\begin{array}{c}\text { Nilai } \mathbf{r} \\
\text { Tabel }\end{array}$ & Keterangan \\
\hline Item 1 & 0.583 & 0,361 & Valid \\
\hline Item 2 & 0.409 & 0,361 & Valid \\
\hline Item 3 & 0.555 & 0,361 & Valid \\
\hline Item 4 & 0.459 & 0,361 & Valid \\
\hline $\begin{array}{l}\text { Sumber : pengolahan } \\
\text { SPSS 17.00 }\end{array}$ & & &
\end{tabular}

Berdasarkan Tabel di atas, pengujian validitas dimulai dari uji validitas variabel kualitas produk (X1) dari 4 butir pertanyaan yang ada, ditemukan semua item pernyataan valid. Hasil uji validitas 4 item diperoleh bahwa nilai korelasi lebih besar dari nilai korelasi kritis atau 0.361. Dengan demikian semua item pernyataan variabel kualitas produk (X1) dapat digunakan untuk pengujian lebih lanjut.

Tabel 3

\section{Hasil Uji Validitas variabel} harga

\begin{tabular}{cccc}
\hline $\begin{array}{c}\text { No Item } \\
\text { Pernyataan }\end{array}$ & $\begin{array}{c}\text { Nilai r } \\
\text { Hitung }\end{array}$ & $\begin{array}{c}\text { Nilai r } \\
\text { Kritis }\end{array}$ & Keterangan \\
\hline Item 1 & 0.482 & 0,361 & Valid \\
\hline Item 2 & 0.362 & 0,361 & Valid \\
\hline Item 3 & 0.579 & 0,361 & Valid \\
\hline Item 4 & 0.475 & 0,361 & Valid \\
\hline Item 5 & 0.443 & 0,361 & Valid \\
\hline
\end{tabular}

Sumber : pengolahan data menggunakan SPSS 17.00

Berdasarkan Tabel di atas, pengujian validitas dimulai dari uji validitas variabel harga (X2) dari 5 butir pertanyaan yang ada, ditemukan semua item pernyataan valid. Hasil uji validitas diperoleh bahwa nilai korelasi lebih besar dari nilai korelasi kritis atau 0.361 . Dengan demikian semua item pernyataan variabel harga (X2) dapat digunakan untuk pengujian lebih lanjut.

Tabel 4

Hasil Uji Validitas variabel Promosi

\begin{tabular}{cccc}
\hline $\begin{array}{c}\text { No Item } \\
\text { Pernyataan }\end{array}$ & $\begin{array}{c}\text { Nilai r } \\
\text { Hitung }\end{array}$ & $\begin{array}{c}\text { Nilai r } \\
\text { Kritis }\end{array}$ & Keterangan \\
\hline Item 1 & 0.560 & 0,361 & Valid \\
\hline Item 2 & 0.429 & 0,361 & Valid \\
\hline Item 3 & 0.385 & 0,361 & Valid \\
\hline Item 4 & 0.542 & 0,361 & Valid \\
\hline Item 5 & 0.429 & 0,361 & Valid \\
\hline
\end{tabular}

Sumber : pengolahan data menggunakan SPSS 17.00

Selanjutnya adalah hasil pengujian validitas untuk item Pernyataan pada variabel promosi (X3) akan disajikan pada Tabel 4 menunjukkan bahwa 5 butir pertanyaan yang ada, ditemukan semua item pernyataan valid. Dari hasil uji validitas diperoleh semua nilai korelasi masing-masing lebih besar dari nilai korelasi kritis atau 
0.361. Dengan demikian semua item pernyataan variabel promosi (X3) dapat digunakan untuk pengujian lebih lanjut.

Tabel 5

Hasil Uji Validitas variabel Tempat Pendistribusian

\begin{tabular}{cccc}
\hline $\begin{array}{c}\text { No Item } \\
\text { Pernyataan }\end{array}$ & $\begin{array}{c}\text { Nilai r } \\
\text { Hitung }\end{array}$ & $\begin{array}{c}\text { Nilai r } \\
\text { Kritis }\end{array}$ & Keterangan \\
\hline Item 1 & 0.383 & 0,361 & Valid \\
\hline Item 2 & 0.402 & 0,361 & Valid \\
\hline Item 3 & 0.562 & 0,361 & Valid \\
\hline Item 4 & 0.378 & 0,361 & Valid \\
\hline $\begin{array}{l}\text { Sumber : } \\
\text { SPSS 17.00 }\end{array}$ &
\end{tabular}

Berdasarkan Tabel 5 di atas, pengujian validitas dimulai dari uji validitas variabel tempat pendistribusian (X4) dari 4 butir pertanyaan yang ada, ditemukan semua item pernyataan valid. Hasil uji validitas diperoleh bahwa nilai korelasi lebih besar dari nilai korelasi kritis atau 0.361. Dengan demikian semua item perrnyataan variabel tempat pendistribusi (X4) dapat digunakan untuk pengujian lebih lanjut.

Tabel 6

Hasil Uji Validitas variabel keputusan pembelian

\begin{tabular}{cccc}
\hline $\begin{array}{c}\text { No Item } \\
\text { Pernyataan }\end{array}$ & $\begin{array}{c}\text { Nilai r } \\
\text { Hitung }\end{array}$ & $\begin{array}{c}\text { Nilai r } \\
\text { Kritis }\end{array}$ & Keterangan \\
\hline Item 1 & 0.540 & 0,361 & Valid \\
\hline Item 2 & 0.561 & 0,361 & Valid \\
\hline Item 3 & 0.647 & 0,361 & Valid \\
\hline Item 4 & 0.539 & 0,361 & Valid \\
\hline
\end{tabular}

Sumber : pengolahan data menggunakan SPSS 17.00

Berdasarkan Tabel 6 di atas, pengujian validitas variabel kepuasan konsumen $(\mathrm{Y})$ dari 4 butir pertanyaan yang ada, ditemukan semua item pernyataan valid. Hasil uji validitas diperoleh bahwa nilai korelasi lebih besar dari nilai korelasi kritis atau 0.361. Dengan demikian semua item pernyataan variabel keputusan pembelian (Y) dapat digunakan untuk pengujian lebih lanjut.

\section{Uji Reliabilitas}

Uji reliabilitas adalah suatu uji yang menunjukkan sejauh mana pengukuran itu dapat memberikan hasil yang relatif tidak beda dilakukan pengulangan pengukuran terhadap subjek yang sama. Uji ini hanya dapat dilakukan pada pernyataan-pernyataan yang valid saja. Pengujian reliabilitas dilakukan dengan menggunakan rumus alpha atau Cronbach's Alpha, instrumen yang mempunyai reliabilitasi. Instrumen yang dipakai dalam variabel itu dikatakan handal apabila memiliki cronbach's alpha lebih dari 0,60 (Ghozali, 2016).

Hasil analisis reliabilitas terhadap masing-masing instrumen penelitian diketahui bahwa nilai Koefisien Alpha Cronbach dari masing-masing variabel dapat dilihat pada Tabel 1.7 berikut ini :

Tabel 7

Hasil Uji Reliabilitas Variabel Penelitian

\begin{tabular}{ccccc}
\hline No & Variabel & $\begin{array}{c}\text { Jumlah } \\
\text { Item }\end{array}$ & $\begin{array}{c}\text { Alpha } \\
\text { Cronbach }\end{array}$ & Keterangan \\
\hline 1 & $\mathrm{Y}$ & 4 & 0,697 & Reliabel \\
\hline 2 & $\mathrm{X} 1$ & 4 & 0,602 & Reliabel \\
\hline 3 & $\mathrm{X} 2$ & 5 & 0,621 & Reliabel \\
\hline 4 & $\mathrm{X} 3$ & 5 & 0,646 & Reliabel \\
\hline 5 & $\mathrm{X} 4$ & 4 & 0,628 & Reliabel \\
\hline
\end{tabular}

Sumber : pengolahan data menggunakan SPSS 17.00

Berdasarkan Tabel 7, hasil pengolahan data untuk uji reliabilitas variabel penelitian sebagaimana yang terlihat pada tabel di atas terlihat bahwa semua variabel memiliki angka alpha cronbach lebih besar dari 0,6. Hal ini menandakan bahwa semua variabel penelitian memiliki kuesioner yang handal atau reliabel. 
Dengan demikian dapat disimpulkan bahwa kuesioner yang digunakan untuk mengumpulkan data penelitian handal.

\section{Hasil Analisis Regresi Berganda}

Analisis regresi berganda digunakan untuk mengetahui pengaruh variabel bebas terhadap variabel tidak bebas (terikat) atas perubahan dari setiap peningkatan atau penurunan variabel bebas yang akan mempengaruhi variabel terikat.

Berikut hasil analisis regresi berganda pada tabel 8 .

Tabel 8

Hasil analisis regresi berganda

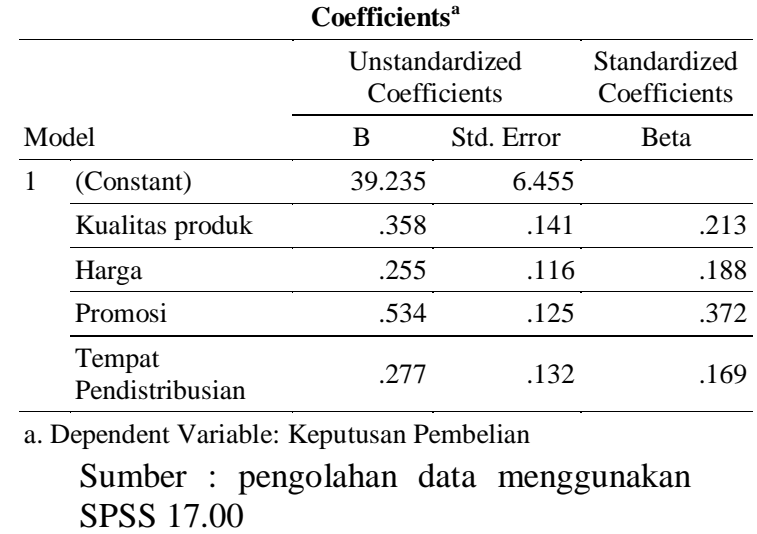

Berdasarkan Tabel 8 diperoleh persamaan dari model regresi dengan variabel independen yaitu kualitas produk, harga, promosi dan tempat pendistribusian. Variabel dependennya adalah keputusan pembelian. Persamaan regresi yang diperoleh dengan melihat nilai pada tabel B pada unstandardized coefficients.

Berdasarkan hasil dari tabel pengujian coefficients di bawah maka dapat disusun persamaan regresi pada penelitian ini sebagai berikut:

$\mathrm{Y}=39.235+0.358 \mathrm{X}_{1}+0.255 \mathrm{X}_{2}+$ $0.534 \mathrm{X}_{3}-0.277 \mathrm{X}_{4}$
Dari rumus diatas dapat diartikan sebagai berikut :

1. Konstanta 39.235 dapat diartikan bahwa jika nilai Kualitas Produk, Harga, Promosi, tempat pendistribusian 0 maka nilai keputusan pembelian 39.235.

2. Kofisien dari variabel $X_{1}$ Kualitas produk $=0.358$ tanda positif adanya hubungan searah antara variabel kualitas produk (independent) terhadap variabel dependent keputusan pembelian, dapat diartikan jika Kualitas Produk naik 1 satuan maka nilai keputusan pembelian naik 0,358 satuan.

3. Kofisien dari variabel $X_{2}$ Harga $=0.255$ tanda positif pada variabel harga adanya hubungan searah antara variabel independent terhadap variabel dependent, dapat diartikan jika Harga naik 1 satuan maka nilai keputusan pembelian naik 0,255 satuan.

4. Kofisien dari variabel $X_{3}$ Promosi $=0.534$ tanda positif pada varibel promosi adanya hubungan searah antara variabel independent terhadap variabel dependent, dapat diartikan pada Variable Promosi naik 1 satuan maka nilai keputusan pembelian naik 0,534 satuan.

5. Kofisien dari variabel $\mathrm{X}_{4}$ Tempat pendistribusaian $=-0.277$ tanda positif pada regresi menandakan ada hubungan searah antara variabel independent terhadap variabel dependent, dapat diartikan jika variabel Tempat pendistribusian naik 1 satuan maka nilai keputusan pembelian mengelami peningkatan sebesar 0,277 satuan terhadap keputusan pembelian, dikarenakan tempat 
yang strategis atau pun mewah, kalau pelayanan di CV. Tjahaja Baru kurang maksimal belum tentu konsumen menyukainya.

\section{Hasil Analisis Koefisien Determinasi \\ Koefisien determinasi $\left(\mathrm{R}^{2}\right)$} tujuannya mengukur seberapa jauh kemampuan variabel independen dalam menerangkan variasi variabel dependen. Berikut hasil analisa determinasi penelitian yang menggunakan SPSS versi 17.00

Tabel 9

Hasil Analisa Determinasi

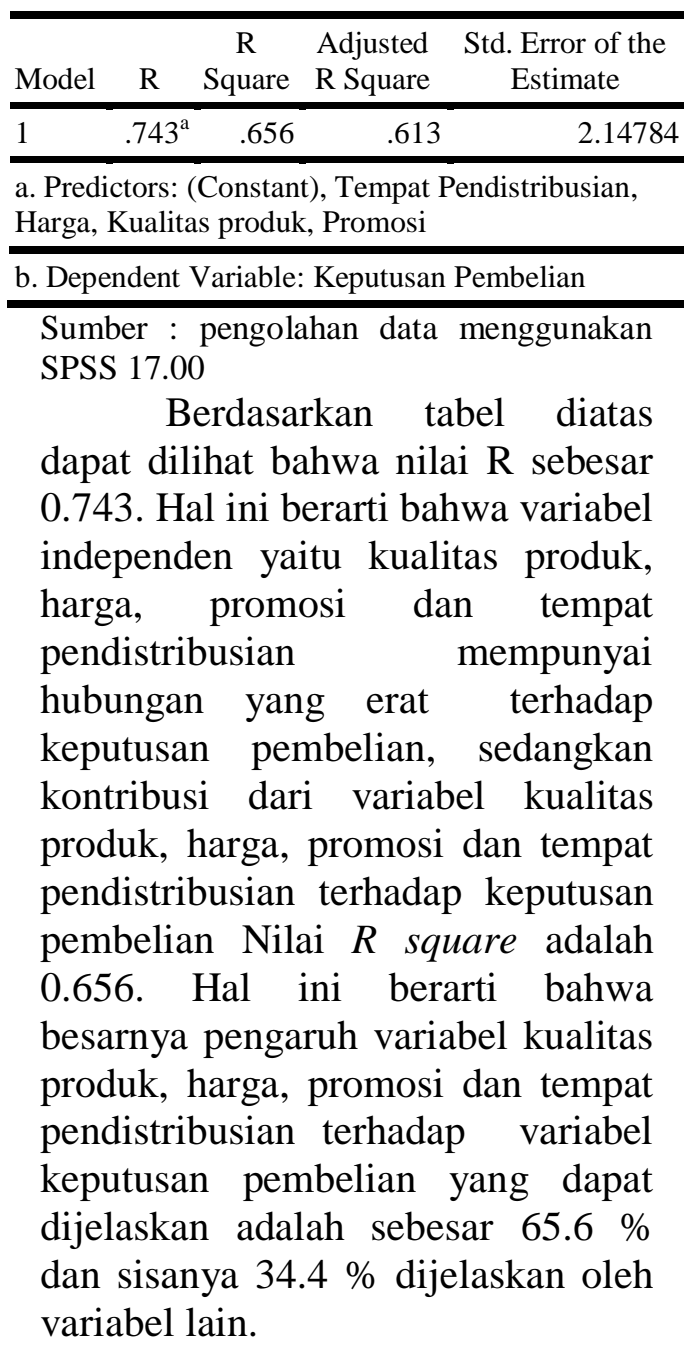

\section{Hasil Uji t}

Uji $t$ digunakan untuk mengetahui apakah dalam model uji regresi variabel independen terhadap variabel dependen secara parsial berpengaruh signifikan. Berikut tabel hasil uji $t$ yang dilakukan menggunakan SPSS versi 17.00. berdasarkan hasil uji t dapat disimpulkan bahwa variabel independen dalan penelitian semuanya memiliki pengaruh secara parsial namun tidak signifikan terhadap keputusan pembelian pada sepeda motor Yamaha di CV. Tjahaja Baru Bukittinggi.

Tabel 1.10

\section{Hasil Uji t}

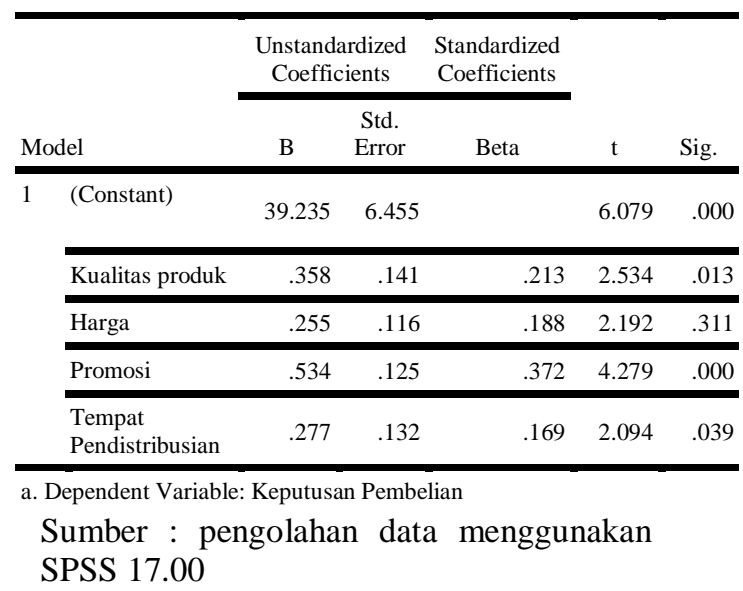

Berdasarkan tabel hasil uji t di atas dapat disimpulkan bahwa kualitas produk berpengaruh positif dan signifikan terhadap keputusan pembelian. Hal ini bisa kita lihat bahwa tingkat signifikansinya sebesar 0.013. artinya nilainya lebih kecil dari 0.05 maka dapat disimpulkan bahwa kualitas produk berpengaruh positif dan signifikan terhadap keputusan pembelian.

Harga juga berpengaruh namun tidak signifikan terhadap keputusan pembelian. Tingkat signifikansinya sebesar 0.311 , artinya lebih besar dari 0.05 . maka 
dapat disimpulkan bahwa harga berpengaruh namun tidak signifikan terhadap keputusan pembelian.

Begitu juga dengan promosi berpengaruh positif dan signifikan terhadap keputusan pembelian. Hal ini bisa kita lihat bahwa tingkat signifikansinya sebesar 0.000 . artinya nilainya lebih kecil dari 0.05 maka dapat disimpulkan bahwa promosi berpengaruh positif dan signifikan terhadap keputusan pembelian.

Tempat pendistribusian, berpengaruh positif dan signifikan terhadap keputusan pembelian. Hal ini bisa kita lihat bahwa tingkat signifikansinya sebesar 0.039 . artinya nilainya lebih kecil dari 0.05 maka dapat disimpulkan bahwa tempat pendistribusian berpengaruh positif dan signifikan terhadap keputusan pembelian..

\section{Uji F}

Uji $F$ digunakan untuk menguji apakah variabel independen secara bersama-sama mempunyai pengaruh terhadap variabel dependennya. Berikut hasil peneitian mengenai Uji $F$ yang dapat dilihat pada 11 .

\section{Tabel 11} Hasil Uji F

\begin{tabular}{|c|c|c|c|c|c|c|}
\hline \multicolumn{2}{|c|}{ Model } & \multirow{2}{*}{$\begin{array}{c}\begin{array}{c}\text { Sum of } \\
\text { Squares }\end{array} \\
489.077\end{array}$} & \multirow{2}{*}{$\frac{\mathrm{df}}{2}$} & \multirow{2}{*}{$\begin{array}{c}\text { Mean } \\
\text { Square } \\
244.538\end{array}$} & \multirow{2}{*}{$\frac{F}{7.104}$} & \multirow{2}{*}{$\frac{\text { Sig. }}{.004^{\mathrm{a}}}$} \\
\hline 1 & Regression & & & & & \\
\hline & Residual & 722.923 & 21 & 34.425 & & \\
\hline & Total & 1212.000 & 23 & & & \\
\hline
\end{tabular}

Sumber : pengolahan data menggunakan SPSS 17.00

Berdasarkan Tabel 11 dapat dilihat bahwa tingkat signifikansi Uji F sebesar 0.004. Maka dapat disimpulkan bahwa variabel kualitas produk, harga, promosi dan tempat pendistribusian secara serentak atau bersama-sama mempunyai pengaruh signifikan terhadap variabel keputusan pembelian. Hal ini di karenakan nilai signifikansinya lebih kecil dari 0.05 .

\section{PENUTUP \\ Kesimpulan}

Berdasarkan hasil analisis dari penelitian penulis mengenai analisis pengaruh kualitas produk, harga, promosi dan tempat pendistibusian terhadap keputusan pembelian sepeda motor Yamaha pada CV. Tjahaja Baru Bukittinggi, maka diperoleh kesimpulan sebagai berikut :

1. Terdapat pengaruh yang positif dan signifikan antara variabel kualitas produk (X1) terhadap keputusan pembelian motor Yamaha di CV. Tjahaja Baru Bukittinggi. Hipotesis di terima pada penelitian ini. Karena hasil penelitian bahwa kualitas produk berpengaruh positif dan signifikan terhadap keputusan pembelian motor Yamaha di CV. Tjahaja Baru Bukittinggi. Hal ini di karenakan sepeda motor Yamaha memiliki kualitas yang sama dengan dealer motor Yamaha lainnya. Tidak berbeda dengan CV. Tjahaja Baru Bukittinggi.

2. Terdapat pengaruh yang positif tapi tidak signifikan antara Harga (X2) terhadap keputusan pembelian motor Yamaha pada CV.Tjahaja Baru di Bukittinggi. Hipotesis di tolak pada penelitian ini. Karena hasil penelitian bahwa harga berpengaruh namun tidak signifikan terhadap keputusan pembelian motor Yamaha di CV. Tjahaja Baru 
Bukittinggi. Hal ini di karenakan sepeda motor Yamaha jika mengalami kenaikan harga maka keputusan pembelian tetap ada tapi tidak sebanyak sebelum harga meningkat di CV. Tjahaja Baru Bukittinggi.

3. Terdapat pengaruh positif dan signifikan anatar Iklan / Promosi (X3) terhadap keputusan pembelian motor Yamaha pada CV.Tjahaja Baru di Bukittinggi. Hipotesis di terima pada penelitian ini. Karena hasil penelitian bahwa promosi berpengaruh positif signifikan terhadap keputusan pembelian motor Yamaha di CV. Tjahaja Baru Bukittinggi. Hal ini di karenakan promosi sepeda motor Yamaha seperti event-event tertentu hampir sama di adakan di dealer motor Yamaha Lainnya.

4. Terdapat pengaruh positif dan signifikan antara Tempat/ Pendistribusian (X4) terhadap keputusan pembelian motor Yamaha pada CV.Tjahaja Baru di Bukittinggi. Hipotesis di terima pada penelitian ini. Karena hasil penelitian bahwa tempat pendistribusian berpengaruh positif dan signifikan terhadap keputusan pembelian motor Yamaha di CV. Tjahaja Baru Bukittinggi. Hal ini di karenakan sepeda motor Yamaha memiliki tempat pendistribusian awal yang sama dengan dealer Motor Yamaha Lainnya. Namun akan berpengaruh pada kecepatan waktu pendistribusian jika tempat distributor jauh dari CV. Tjahaja Baru

5. Terdapat pengaruh Bauran Pemasaran (Produk, Harga, Promosi dan Tempat/
Pendistribusian) terhadap keputusan pembelian sepeda motor Yamaha pada CV.Tjahaja Baru di Bukittinggi. Hipotesis di terima pada penelitian ini. Karena hasil penelitian bahwa Bauran Pemasaran (Produk, Harga, Promosi dan Tempat/ Pendistribusian) berpengaruh positif dan signifikan secara simultan terhadap keputusan pembelian motor Yamaha di CV. Tjahaja Baru Bukittinggi.

\section{Saran}

Dari hasil penelitian di harapkan pihak praktisi dapat memperbaiki lagi elemen-elemen bauran pemasaran demi meningkatkan penjualan motor Yamaha di CV Tjahaja Baru Bukittinggi. Selanjutnya bagi penelitian yang akan dating agar meneliti dalam konsep yang lebih besar lagi dengan memperbanyak variable yang diteliti.

\section{DAFTAR PUSTAKA}

Arikunto, S. 2010. Prosedur penelitian : Suatu Pendekatan Praktik. (Edisi. Revisi). Jakarta : Rineka Cipta.

Alex S. Nitisemito. 2010. Manajemen personalia Manajemen Sumber Daya Manusia. Edisi Ketiga. Jakarta : Ghalia Indonesia.

Ghozali, Imam. 2016. Aplikasi Analisis Multivariete dengan Program IBM. SPSS 21. Semarang: Badan Penerbit Universitas Diponegoro.

Kotler, Philip and Kevin Lane Keller, 2016. Marketing Managemen, 15th Edition, Pearson Education,Inc.

Kotler, Philip \& Armstrong, G. 2012. 
Pemasaran. Edisi. 13. Jilid 1. Jakarta: Erlangga.

Prasetijo, R \& Ihalauw, J. 2005. Perilaku Konsumen, Andi Offset, Yogyakarta.

Sugiyono. 2012. Metode Penelitian Kuantitatif Kualitatif dan $R \& D$. Bandung: Alfabeta.

Tjiptono, Fandy. 2015. Strategi

Pemasaran. Edisi 3. Yogyakarta : ANDI.

William, J. Stanton., Michael, J.Etzel., \& Bruce, J.Walker. 2012. Dasar-dasar Manajemen Pemasaran, cetakan 1. Penerbit Mandar Maju 